\title{
KONSEP BELAJAR DAN PEMBELAJARAN
}

\author{
Muh. Sain Hanafy \\ Fakultas Tarbiyah dan Keguruan UIN Alauddin Makassar \\ Kampus II: Jalan Sultan Alauddin Nomor 36 Samata-Gowa \\ Email: mshanafy62@gmail.com
}

\begin{abstract}
Abstrak:
Belajar dan pembelajaran merupakan dua konsep yang saling berhubungan dan tidak dapat dipisahkan. Keduanya merupakan aktivitas utama dalam pendidikan. Belajar dimaknai sebagai proses perubahan perilaku sebagai hasil interaksi individu dengan lingkungannya. Perubahan perilaku hasil belajar bersifat kontinyu, fungsional, positif, aktif, dan terarah. Proses perubahan tingkah laku dapat terjadi dalam berbagai kondisi berdasarkan penjelasan dari para ahli pendidikan dan psikologi. Adapun pembelajaran adalah kegiatan yang berproses melalui tahapan perancangan, pelaksanaan, dan evaluasi. Pembelajaran merupakan usaha yang dilakukan untuk menfasilitasi terjadinya proses belajar pada anak didik. Pembelajaran dimaknai pula sebagai interaksi peserta didik dengan pendidik dan sumber belajar dalam suatu lingkungan belajar. Dengan demikian, efektivitas sebuah proses pembelajaran ditentukan oleh interaksi ketiga komponen tersebut.
\end{abstract}

\begin{abstract}
Learning and instruction are the two concepts that are related to each other, and they cannot be separated. Both of them are the main activities in education. Learning is defined as the process of changing behavior as a result of individual interaction with their environment. The changing of behavior is continuous, functional, positive, and directed. The process of changing behavior stimulated in many different conditions based on the explanation from educational and psychological experts. Instruction is defined as the activities processing from planning, implementation, and evaluation. Instruction is the effort to facilitate students' learning. Instruction is also defined as the interaction of students, educators, and learning resources in a learning environment. Therefore, the effectiveness of instruction is determined by the interaction of these three components.
\end{abstract}

Kata Kunci:

Peserta didik, pendidik, dan interaksi

BELAJAR dan pembelajaran merupakan aktivitas utama dalam proses pendidikan. Pendidikan secara nasional di Indonesia didefinisikan sebagai usaha sadar dan terencana untuk mewujudkan suasana belajar dan proses pembelajaran, agar peserta didik secara aktif mengembangkan potensi dirinya sehingga memiliki kekuatan spiritual keagamaan, pengendalian diri, kepribadian, kecerdasan, akhlak mulia, serta keterampilan yang diperlukan baik untuk diri peserta didik itu sendiri maupun untuk masyarakat, bangsa, dan negaranya. ${ }^{1}$ 
Terdapat unsur penting dalam definisi pendidikan secara nasional, yaitu usaha sadar dan terencana, mewujudkan suasana belajar dan proses pembelajaran yang memungkinkan bagi peserta didik untuk aktif mengembangkan potensi yang dimilikinya, serta membekali peserta didik dengan kekuatan spiritual keagamaan, pengendalian diri, kepribadian, kecerdasan, akhlak mulia, dan keterampilan yang diperlukan bagi diri, masyarakat, bangsa, dan negara peserta didik. Suasana belajar dan proses pembelajaran yang memungkinkan bagi peserta didik untuk aktif mengembangkan potensi yang dimilikinya hanya dapat diwujudkan melalui proses interaksi yang bersifat edukatif antara dua unsur manusiawi, yaitu peserta didik sebagai pihak yang belajar dan guru sebagai pihak yang mengajar dengan peserta didik sebagai subjek pokoknya.

Kelangsungan proses interaksi yang bersifat edukatif antara peserta didik dengan guru dalam proses pembelajarannya, dibutuhkan komponen-komponen pendukung yang sekaligus mencirikan terjadinya interkasi edukatif tersebut. Komponen dimaksud adalah tujuan yang ingin dicapai, bahan/pesan yang menjadi isi interaksi, peserta didik yang aktif mengalami proses pembelajaran, guru yang melaksanakan proses pembelajaran, metode untuk mencapai tujuan pembelajaran, situasi yang memungkinkan proses pembelajaran berjalan dengan baik, dan penilaian terhadap hasil interaksi dalam proses pembelajaran. ${ }^{2}$

Belajar dan pembelajaran berlangsung dalam suatu proses yang dimulai dengan perencanaan berbagai komponen dan perangkat pembelajaran agar dapat diimplementasikan dalam bentuk interaksi yang bersifat edukatif, dan diakhiri dengan evaluasi untuk mengukur dan menilai tingkat pencapaian tujuan pembelajaran yang diharapkan. Belajar dan pembelajaran merupakan suatu proses yang komplek dengan menyatukan komponen-komponen yang memiliki karakteristik tersendiri yang secara terintegrasi, saling terkait dan mempengaruhi untuk mencapai tujuan atau kompetensi yang diharapkan. Komponen-komponen pembelajaran yang dimaksud, mencakup tujuan, materi, metode, media, dan sumber, evaluasi, peserta didik, guru, dan lingkungan. ${ }^{3}$

Belajar dan pembelajaran merupakan aktivitas yang terencana untuk mencapai tujuan tertentu yang dicirikan dengan keterlibatan sejumlah komponen yang saling terkait satu sama lain. Komponen-komponen dalam belajar dan pembelajaran yang dimaksud disebut perangkat pembelajaran yang teriri atas rencana pelaksanaan pembelajaran, alat pembelajaran yang mencakap metode, media, dan sumber belajar, serta alat evaluasi, baik berupa tes maupun nontes. Belajar dan pembelajaran, baik sebagai proses maupun sebagai sistem telah mendapat perhatian dari para ahli dengan sudut pandang yang berbeda sesuai dengan bidang keahlian masing-masing sehingga melahirkan konsep dan teori belajar dan pembelajaran yang beragam.

Berdasarkan uraian di atas, belajar dan pembelajaran sebagai suatu konsep dan teori sebagaimana yang telah dikembangkan oleh para ahli, merupakan masalah pokok yang dirumuskan sebagai berikut: Bagaimana konsep tentang belajar dan pembelajaran? 


\section{PEMBAHASAN}

\section{Konsep Belajar dan Pembelajaran}

Belajar dan pembelajaran merupakan dua konsep yang saling terkait satu satu sama lain, bagaikan dua sisi mata uang yang sulit untuk dipisahkan. Aktivitas belajar peserta didik hanya dimungkinkan berlangsung dalam suatu proses pembelajaran yang dapat memberi kesempatan bagi mereka untuk belajar dengan baik. Sebaliknya, proses pembelajaran dapat berlangsung dengan baik bila medapat respons dari peserta didik. Keterkaitan antara belajar dan pembelajaran tampak pada konsep belajar dan pembelajaran.

\section{Konsep Belajar}

Belajar dalam arti luas merupakan suatu proses yang memungkinkan timbulnya atau berubahnya suatu tingkah laku baru yang bukan disebabkan oleh kematangan dan sesuatu hal yang bersifat sementara sebagai hasil dari terbentuknya respons utama. ${ }^{4}$ Belajar merupakan aktivitas, baik fisik maupun psikis yang menghasilkan perubahan tingkah laku yang baru pada diri individu yang belajar dalam bentuk kemampuan yang relatif konstan dan bukan disebabkan oleh kematangan atau sesuatu yang bersifat sementara.

Perubahan kemampuan yang disebabkan oleh kematangan, pertumbuhan, dan perkembangan seperti anak yang mampu berdiri dari duduknya atau perubahan fisik yang disebabkan oleh kecelakaan tidak dapat dikategorikan sebagai hasil dari perbuatan belajar meskipun perubahan itu berlangsung lama dan konstan. Menurut Slameto bahwa belajar ialah suatu proses yang dilakukan seseorang untuk memperoleh suatu perubahan tingkah laku yang baru secara keseluruhan sebagai hasil dari pengalamannya sendiri dalam berinteraksi dengan lingkungannya. ${ }^{5}$

Perubahan tingkah laku yang baru sebagai hasil dari perbuatan belajar terjadi secara sadar, bersifat kontinu dan fungsional, bersifat positif dan aktif, bersifat konstan, bertujuan atau terarah, serta mencakup seluruh aspek tingkah laku. Ciri-ciri perubahan tingkah laku sebagai hasil dari perbuatan belajar tersebut tampak dengan jelas dalam berbagai pengertian belajar menurut pandangan para ahli pendidikan dan psikologi

1. Belajar menurut Pandangan B. F. Skinner

Belajar menurut Skinner adalah menciptakan kondisi peluang dengan penguatan (reinforcement), sehingga individu akan bersungguh-sungguh dan lebih giat belajar dengan adanya ganjaran (funnistment) dan pujian (rewards) dari guru atas hasil belajarnya. Skinner membuat perincian lebih jauh dengan membedakan adanya dua macam respons. Pertama, respondent response, yaitu respons yang ditimbulkan oleh perangsang-perangsang tertentu yang disebut eliciting stimuli menimbulkan responsrespons yang secara relatif tetap, misalnya makanan yang menimbulkan keluarnya air liur. Pada umumnya, perangsang-perangsang yang demikian itu mendahului respons yang ditimbulkannya. Kedua, operant response, yaitu respons yang timbul dan 
berkembangnya diikuti oleh perangsang-perangsang tertentu yang disebut reinforcing stimuli atau reinforce, karena perangsang-perangsang tersebut memperkuat respons yang telah dilakukan oleh organisme. Jadi, seorang akan menjadi lebih giat belajar apabila mendapat hadiah sehingga responsnya menjadi lebih intensif atau kuat. ${ }^{6}$

Belajar menurut pandangan Skinner adalah kesempatan terjadinya peristiwa yang menimbulkan respons belajar, baik konsekuensinya sebagai hadiah maupun teguran atau hukuman. Dengan demikian, pemilihan stimulus yang deskriminatif dan penggunaan penguatan dapat merangsang individu lebih giat belajar, sehingga belajar merupakan hubungan antara stimulus dengan respons (S-R).

2. Belajar menurut Pandangan Robert M. Gagne

Gagne sebagai yang dikutip oleh Sagala memandang bahwa belajar adalah perubahan yang terjadi dalam kemampuan manusia setelah belajar secara terus-menerus yang bukan hanya disebabkan oleh proses pertumbuhan saja. Belajar terjadi apabila suatu situasi stimulus bersama dengan isi ingatan memengaruhi individu sedemikian rupa sehingga perbuatannya berubah dari waktu sebelum ia mengalami situasi itu ke waktu setelah ia mengalami situasi tadi.7

Pandangan Gagne di atas menunjukkan bahwa belajar adalah adanya stimulus yang secara bersamaan dengan isi ingatan memengaruhi perubahan tingkah laku dari waktu ke waktu. Karena itu, belajar dipengaruhi oleh faktor internal berupa isi ingatan dan faktor ekternal berupa stimulus yang bersumber dari luar diri individu yang belajar.

Gagne membagi segala sesuatu yang dipelajari individu yang disebut the domains of learning itu menjadi lima kategori. Pertama, keterampilan motoris (motor skill), yaitu koordinasi dari berbagai gerakan badan. Kesua, informasi verbal, yaitu menjelaskan sesuatu dengan berbicara, menulis, dan menggambar. Ketiga, kemampuan intelektual, yaitu menggunakan simbol-simbol dalam mengadakan interaksi dengan dunia luar. Keempat, strategi kognitif, yaitu belajar mengingat dan berpikir memerlukan organisasi keterampilan yang internal (internal organized skill). Kelima, sikap, yaitu sikap belajar yang penting dalam proses belajar. ${ }^{8}$

Berdasarkan uraian di atas, Gagne memandang bahwa belajar dipengaruhi oleh faktor dalam diri dan faktor dari luar diri individu belajar yang saling berintekasi, sehingga kondisi eksternal berupa stimulus dari lingkungan belajar dan kondisi internal yang berupa keadaan internal dan proses kognitif individu yang saling berinteraksi dalam memperoleh hasil belajar yang dikategorikan sebagai keterampilan motoris (motorik skill), informasi verbal, kemampuan intelektual, strategi kognitif, dan sikap.

3. Belajar menurut Pandangan Jean Piaget

Piaget adalah seorang psikolog yang fokus mempelajari berpikir pada anakanak sebab ia yakin dengan cara berpikir anak-anak akan dapat menjawab pertanyaan-pertanyaan epistemologi. Piaget berpendapat bahwa ada dua proses yang terjadi dalam pekembangan kognitif anak, yaitu proses assimilations dan proses accommodations. ${ }^{9}$ Proses assimilations, yaitu menyesuaikan atau mencocokkan informasi yang 
baru diperoleh dengan informasi yang telah diketahui sebelumnya dan mengubahnya bila perlu. Adapun proses accommodations, yaitu menyusun dan membangun kembali atau mengubah informasi yang telah diketahui sebelumnya sehingga informasi yang baru dapat disesuaikan dengan lebih baik.

Piaget mengembangkan teori kognitif tersebut dalam konteks teori keseimbangan yang disebut accomodation. Teori ini memberi penjelasan bahwa struktur fungsi kognitif dalam berubah kalau individu berhadapan dengan hal-hal baru yang tidak dapat diorganisasikan ke dalam struktur yang telah ada (association). Akomodasi menurut Piaget adalah hasil dari yang ditambahkan dan diciptakan oleh lingkungan dan pengamatan yang tidak sesuai dengan apa yang diketahui dan dipikirkan. ${ }^{10}$ Piaget menjelaskan tiga cara bagi anak untuk sampai pada cara mengetahui sesuatu, yaitu melalui interaksi sosial, melalui pengetahuan fisik, dan melalui logico-mathematical. ${ }^{11}$

Jelaslah bahwa Piaget memandang belajar sebagai suatu proses asimilasi dan akomodasi dari hasil assosiasi dengan lingkungan dan pengamatan yang tidak sesuai antara informasi baru yang diperoleh dengan informasi yang telah diketahui sebelumnya.

\section{Belajar menurut Pandangan Carl R. Rogers}

Rogers menitikberatkan pada segi pengajaran dibanding siswa yang belajar dalam praktik pendidikan yang ditandai dengan peran guru yang dominan dan siswa hanya menghafalkan pelajaran dengan alasan bahwa pentingnya guru memperhatikan prinsip pendidikan dan pembelajaran adalah: (1) manusia memiliki kekuatan wajar untuk belajar sehingga siswa tidak harus belajar tentang hal-hal yang tidak berarti, (2) siswa akan mempelajari hal-hal yang bermakna bagi dirinya, (3) pengorganisasian bahan pengajaran berarti mengorganisasikan bahan dan ide baru sebagai bagian yang bermakna bagi siswa, (4) belajar yang bermakna bagi masyarakat modern berarti belajar tentang proses-proses belajar, keterbukaan belajar mengalami sesuatu, bekerjasama dengan melakukan pengubahan diri secara terus menerus, (5) belajar yang optimal akan terjadi bila siswa berpartisipasi secara bertanggung jawab dalam proses pembelajaran, (6) belajar mengalami (experiental learning) dapat terjadi bila siswa mengevaluasi dirinya sendiri, dan (7) belajar mengalami menuntut keterlibatan siswa secara penuh dan sungguh-sungguh. ${ }^{12}$

Belajar dalam pandangan Rogers di atas pada dasarnya bertumpu pada prinsip kebebasan dan perbedaan individu dalam pendidikan. Dengan demikian, peserta didik akan lebih mengenal dirinya, menerima diri sebagaimana adanya, dan akhirnya merasa bebas memilih dan berbuat menurut individualitasnya dengan penuh tanggung jawab.

5. Belajar menurut Pandangan Benjamin S. Bloom

Penelitian yang dilakukan oleh Bloom dalam mengamati kecerdasan anak pada rentang waktu tertentu menemukan bahwa pengukuran kecerdasan anak pada usia 15 tahun merupakan hasil pengembangan dari anak usia dini. Bloom mengembangkan taksonomi dari tujuan pendidikan dengan menyusun pengalaman-pengalaman 
dan pertanyaan-pertanyaan secara bertingkat dari recall sampai pada terapannya dengan suatu keyakinan bahwa anak dapat menguasai tugas-tugas yang dihadapkan kepada mereka di sekolah, tetapi mengakui adanya anak yang yang membutuhkan waktu lebih lama dan bimbingan yang lebih intensif dibanding teman seusianya. ${ }^{13}$

Taksonomi tujuan-tujuan yang disusun Bloom disebut taxonomi bloom yang terdiri atas tiga kawasan (domain), yaitu: domain kognitif, domain afektif, dan domain psikomotor. Domain-domain tersebut merupakan kemampuan-kemampuan yang diharapkan dimiliki peserta didik setelah mengikuti proses pendidikan.

Domain kognitif mencakup kemampuan intelektual mengenal lingkungan yang terdiri atas enam macam kemampuan yang disusun secara hierarkis dari yang paling sederhana sampai yang paling kompleks, yaitu pengetahuan, pemahaman, penerapan, analysis, sintesis, dan penilaian. Domain afektif mencakup kemampuan-kemampuan emosional dalam mengalami dan menghayati sesuatu hal yang meliputi lima macam kemampuan emosional secara hierarkis, yaitu kesadaran, partisipasi, penghayatan nilai, pengorganisasian nilai, dan karakterisasi diri. Domain psikomotor merupakan kemampuan-kemampuan motorik dalam menggiatkan dan mengkoordinasikan gerakan yang terdiri atas gerakan refleks, gerakan dasar, kemampuan perseptual, kemampuan jasmani, gerakan-gerakan terlatih, dan komunikasi nondiskursif. ${ }^{14}$

Belajar dalam pandangan Bloom pada dasarnya adalah perubahan kualitas kemampuan kognitif, afektif, dan psikomotorik untuk meningkatkan taraf hidup peserta didik, baik sebagai pribadi dan anggiota masyarakat maupun sebagai makhluk Tuhan Yang Maha Esa.

6. Belajar menurut Pandangan Jerume S. Bruner

Bruner beranggapan bahwa belajar merupakan pengembangan kategori-kategori yang saling berkaitan sedemikian rupa hingga setiap individu mempunyai model yang unik tentang alam dan pengembangan suatu sistem pengodean (coding). Sesuai dengan model ini, belajar baru dapat terjadi dengan mengubah model yang terjadi melalui pengubahan kategori-kategori, menghubungkan kategori-kategori dengan suatu cara baru, atau dengan menambahkan kategori-kategori baru. ${ }^{15}$

Pendidikan menurut Brunner merupakan usaha yang kompleks untuk menyesuaikan kebudayaan dengan kebutuhan anggotanya, dan menyesuaikan anggotanya dengan cara mereka mengetahui kebutuhan kebudayaan. ${ }^{16}$ Pandangan Bruner tentang belajar dapat diuraikan sebagai pendekatan kategorisasi. Semua interaksi individu dengan alam akan senantiasa melibatkan kategori-kategori yang dibutuhkan untuk memfungsikan manusia. Kategorisasi menyederhanakan kekompleksitas dalam lingkungan individu.

Mengacu pada uraian tentang belajar menurut pandangan para ahli pendidikan dan psikologi di atas, secara singkat dapat disimpulkan bahwa belajar merupakan aktivitas psiko dan fisik yang menghasilkan perubahan atas pengetahuan, sikap, dan keterampilan yang relatif bersifat konstan. Meskipun para ahli sepakat bahwa inti dari perbuatan belajar adalah perubahan tingkah laku, tetapi terdapat bermacammacam cara untuk mendapatkan perubahan itu. Setiap perbuatan belajar mempunyai 
ciri masing-masing sesuai dengan sudut pandang masing-masing ahli. ${ }^{17}$ Oleh karena itu, ahli psikologi membedakan perbuatan belajar menjadi beberapa jenis menurut cirinya masing-masing.

1. Belajar Abstrak

Belajar abstrak ialah belajar yang menggunakan cara-cara berpikir abstrak untuk memperoleh pemahaman dan pemecahan masalah-masalah yang tidak nyata. Termasuk dalam jenis belajar ini adalah belajar matematika, astronomi, filsafat, materi pembelajaran akidah yang memerlukan peranan akal yang kuat di samping penguasaan atas prinsip, konsep, dan generalisasi. ${ }^{18}$

Jenis belajar abstrak menitikberatkan pada peranan akal dan penguasaan prinsip, konsep, dan generalisasi untuk memperoleh pemahaman dan pemecahan masalah (problem solving) dalam mempelajari hal-hal yang bersifat abstrak. Termasuk dalam prinsip adalah penerapan dalil, hukum, atau rumus, dan konsep mencakup definisi, identifikasi, klasifikasi, dan dan ciri-ciri khusus, ${ }^{19}$ sedangkan generalisasi adalah menarik kesimpulan yang refresentatif dan berlaku secara umum atas fakta yang diamati

2. Belajar Keterampilan

Belajar jenis ini adalah belajar dengan menggunakan gerakan-gerakan motorik, yaitu berhubungan dengan urat-urat saraf dan otot-otot (neuromuscular) yang bertujuan untuk memperoleh dan menguasai keterampilan-keterampilan jasmaniah tertentu. ${ }^{20}$ Termasuk belajar dalam jenis ini adalah olahraga, musik, menari, melukis, memperbaiki benda-benda elektronik, dan sebagian materi pembelajaran agama seperti ibadah salat dan haji.

3. Belajar Sosial

Belajar sosial pada dasarnya adalah belajar memahami masalah-masalah dan teknik-teknik untuk memecahkan masalah-masalah sosial. Tujuannya adalah untuk menguasai pemahaman dan kecakapan dalam memecahkan masalah-masalah sosial, seperti masalah keluarga, masalah persahabatan, masalah kelompok, dan masalahmasalah lain yang bersifat kemasyarakatan. ${ }^{21}$

Belajar dalam jenis ini dimaksudkan untuk mengatur dorongan hasrat pribadi demi kepentingan bersama dan memberi peluang kepada orang lain atau kelompok lain untuk memenuhi kebutuhannya secara berimbang dan proporsional. Termasuk dalam jenis belajar sosial adalah bahan pelajaran sosial seperti pelajaran agama dan PPKn.

4. Belajar Pemecahan Masalah

Belajar pemecahan masalah (problem solving) pada dasarnya adalah belajar menggunakan metode-metode ilmiah atau berpikir secara sistematis, logis, teratur, dan teliti untuk memperoleh kemampuan dan kecakapan kognitif dalam memecahkan masalah secara rasional, lugas, dan tuntas. ${ }^{22}$ Belajar pemecahan masalah menun- 
tut kemampuan dalam menguasai konsep-konsep, prinsip-prinsip, generalisasi, dan tilikan akal. Untuk keperluan ini, hampir semua bidang studi dapat dijadikan sarana belajar pemecahan masalah, terutama pembelajaran eksakta.

\section{Belajar Rasional}

Belajar rasional erat kaitannya dengan belajar pemecahan masalah, yaitu menggunakan kemampuan berpikir secara logis dan rasional agar memiliki kemampuan memecahkan masalah dengan menggunakan pertimbangan dan strategi akal sehat, logis, dan sistematis. ${ }^{23}$ Belajar jenis ini tidak memberi penekanan pada pembelajaran eksakta, sehingga bidang studi noneksakta pun dapat memberi efek yang sama dengan bidang studi eksakta dalam belajar rasional.

\section{Belajar Kebiasaan}

Belajar kebiasaan diartikan sebagai proses pembentukan kebiasaan-kebiasaan baru atau perbaikan kebiasaan-kebiasaan yang telah ada. Tujuan belajar jenis ini adalah memperoleh sikap-sikap dan kebiasaan-kebiasaan perbuatan baru yang lebih tepat dan positif selaras dengan kebutuhan ruang dan waktu (kontekstual). ${ }^{24}$

Meskipun jenis belajar kebiasaan lebih tepat dilaksanakan dalam konteks pendidikan informal, namun tidak tertutup kemungkinan penggunaan pembelajaran agama Islam dan PPKn sebagai sarana belajar kebiasaan bagi anak didik agar sikap dan kebiasaannya selaras dengan norma-norma dan tata nilai yang berlaku.

\section{Belajar Apresiasi}

Belajar apresiasi adalah belajar mempertimbangkan (judgment) arti penting atau nilai suatu objek. Tujuannya, agar peserta didik memperoleh dan mengembangkan kecakapan ranah rasa (affective skill) sebagai kemampuan menghargai nilai objek secara tepat. ${ }^{25}$ Bidang-bidang studi yang dapat menunjang pencapaian tujuan belajar apresiasi antara lain bahasa dan sastra, kerajinan tangan, kesenian, dan menggambar, di samping materi seni baca tulis Alquran pada bidang studi Pendidikan Agama Islam.

\section{Belajar Pengetahuan}

Belajar pengetahuan ialah belajar dengan cara melakukan penyelidikan secara mendalam terhadap objek pengetahuan tertentu yang bertujuan untuk menambah informasi dan pemahaman terhadap pengetahuan tertentu yang biasanya lebih rumit dan memerlukan kiat khusus dalam mempelajarinya, seperti menggunakan alat-alat laboratorium dan penelitian lapangan. ${ }^{26}$ Bidang studi bahasa dan sains dapat menjadi sarana dalam mengembangkan kegiatan belajar jenis pengetahuan ini.

Bertitik tolak dari berbagai pandangan sejumlah ahli mengenai belajar, ditemukan bahwa walaupun terdapat perbedaan mengenai pengertian dan jenis belajar, namun terdapat kesamaan makna bahwa konsep belajar selalu menunjukkan kepada suatu proses perubahan perilaku seseorang berdasarkan praktek atau pengalaman tertentu. 


\section{Konsep Pembelajaran}

Menurut Undang-undang Republik Indonesia Nomor 20 Tahun 2003 Tentang Sistem Pendidikan Nasional bahwa pembelajaran adalah proses interaksi peserta didik dengan pendidik dan sumber belajar yang berlangsung dalam suatu lingkungan belajar. ${ }^{27}$ Pembelajaran dipandang secara nasional sebagai suatu proses interaksi yang melibatkan komponen-komponen utama, yaitu peserta didik, pendidik, dan sumber belajar yang berlangsung dalam suatu lingkungan belajar. Dengan demikian, proses pembelajaran merupakan suatu sistem, yaitu satu kesatuan komponen yang satu sama lain saling berkaitan dan saling berinteraksi untuk mencapai suatu hasil yang diharapkan secara optimal sesuai dengan tujuan yang telah ditetapkan. ${ }^{28}$

Pembelajaran pada pokoknya merupakan tahapan-tahapan kegiatan guru dan siswa dalam menyelenggarakan program pembelajaran, yaitu rencana kegiatan yang menjabarkan kemampuan dasar dan teori pokok yang secara rinci memuat alokasi waktu, indikator pencapaian hasil belajar, dan langkah-langkah kegiatan pembelajaran untuk setiap materi pokok mata pelajaran

Aktivitas proses pembelajaran ditandai dengan terjadinya interaksi edukatif, yaitu interaksi yang sadar akan tujuan, berakar secara metodologis dari pihak pendidik (guru) dan kegiatan belajar secara pedagogis pada diri peserta didik, berproses secara sistematis melalui tahap rancangan, pelaksanaan, dan evaluasi. Pembelajaran tidak terjadi seketika, melainkan berproses melalui tahapan-tahapan yang dicirikan dengan karakteristik tertentu. Pertama, melibatkan proses mental siswa secara maksimal dalam proses pembelajaran. Kedua, membangun suasana dialogis dan proses tanya jawab secara terus menerus yang diarahkan untuk memperbaiki dan meningkatkan kemampuan berpikir siswa yang pada gilirannya dapat membantu siswa untuk memperoleh pengetahuan yang mereka konstruksi sendiri. ${ }^{29}$

Pembelajaran merupakan usaha pendidik untuk mewujudkan terjadinya proses pemerolehan pengetahuan, penguasaan kemahiran, dan pembentukan sikap dan kepercayaan pada peserta didik. Dengan kata lain, pembelajaran adalah proses yang menfasilitasi peserta didik agar dapat belajar dengan baik. Sehingga dengan demikian untuk dapat menghasilkan proses pembelajaran yang efektif sebagaimana yang diharapkan, maka pendidik perlu memahami teori-teori belajar yang dapat menjadi landasan pelaksanaan pembelajaran. Di antara teori tersebut adalah:

\section{Teori Ilmu Jiwa Daya}

Ahli-ahli Ilmu Jiwa Daya mengemukakan suatu teori bahwa jiwa manusia mempunyai daya-daya seperti daya mengenal, daya mengingat, daya berpikir, daya fantasi, dan sebagainya. Daya-daya ini adalah kekuatan yang tersedia. Manusia hanya memanfaatkan semua daya itu dengan cara melatih sehingga ketajamannya dirasakan ketika dipergunakan untuk sesuatu hal. ${ }^{31}$

Implikasi dari teori belajar menurut Ilmu Jiwa Daya ini adalah belajar hanyalah sebatas melatih semua daya itu. Untuk melatih daya ingat seseorang harus melakukan dengan cara menghafal kata-kata atau angka, istilah-istilah asing, dan sebagai- 
nya, melatih ketajaman berpikir seseorang dengan cara memecahkan masalah dari yang sederhana sampai yang kompleks, meningkatkan daya fantasi seseorang dengan membiasakan diri merenungkan sesuatu. Dengan usaha tersebut, maka dayadaya itu dapat tumbuh dan berkembang di dalam diri seseorang. Oleh karena itu, menurut para ahli Ilmu Jiwa Daya, hasil belajar diperoleh dengan cara melatih semua daya yang ada dalam diri.

Efek teori belajar menurut Ilmu Jiwa Daya terhadap ilmu pengetahuan yang didapat hanyalah bersifat hafalan-hafalan belaka yang biasanya jauh dari pengertian dan pemahaman. Walaupun demikian, teori belajar ini dapat digunakan untuk menghafal rumus, dalil, peristiwa sejarah, dan sebagainya.

\section{Teori Gestalt}

Teori belajar Gestalt lahir di Jerman pada tahun 1912 yang dipelopori dan dikembangkan oleh Max Wertheimer yang diikuti oleh Koffka dan Kohler yang berpandangan bahwa keseluruhan lebih penting dari bagian-bagian, sebab keberadaan bagian-bagian itu didahului oleh keseluruhan. ${ }^{32}$ Hal terpenting dalam belajar adalah penyesuaian pertama, yaitu mendapatkan respons atau tanggapan yang tepat, bukan mengulangi hal-hal yang harus dipelajari, tetapi mengerti atau memperoleh insight.

Teori belajar menurut Ilmu Jiwa Gestalt seringkali disebut field theory atau insight full learning yang memandang manusia yang bukan hanya sekedar makhluk reaksi yang hanya berbuat atau beraksi jika ada perangsang yang memengaruhinya. Menurut para ahli Ilmu Jiwa Daya, manusia adalah individu yang merupakan kebulatan jasmani dan rohani (psiko-fisik) yang berinteraksi dengan dunia luar menurut kepribadiannya yang unik dan dengan caranya yang unik pula. Tidak ada dua orang yang mempunyai pengalaman yang benar-benar sama atau identik terhadap objek atau realita yang sama. ${ }^{33}$

Singkatnya, belajar menurut Ilmu Jiwa Gestalt bahwa faktor pemahaman atau pengertian (insight) merupakan faktor yang penting dalam menghubungkan antara pengetahuan dan pengalaman. Pribadi atau organisme memegang peranan penting dalam belajar karena belajar tidak hanya dilakukan secara reaktif-mekanistis, tetapi dilakukan dengan sadar, bermotif, dan bertujuan.

\section{Teori Asosiasi}

Teori belajar menurut Ilmu Jiwa Asosiasi disebut juga teori Sarbond, yaitu stimulus (rangsangan), respons (tanggapan), dan bond (dihubungkan). Rangsangan diciptakan untuk memunculkan tanggapan kemudian dihubungkan antara keduanya dan terjadilan asosiasi. Teori ini berprinsip bahwa keseluruhan itu sebenarnya terdiri atas penjumlahan bagian-bagian atau unsur-unsurnya. Terdapat dua teori yang sangat terkenal dari aliran Ilmu Jiwa Asosiasi, yaitu: teori Connectionism dari Thorndike dan teori Conditioning dari Ivan P. Pavlov.

\section{Teori Connectionism}

Teori Connectionism ditemukan dan dikembangkan oleh Edward L. Thorndike 
berdasarkan eksperimen yang ia lakukan dengan menggunakan hewan terutama kucing untuk mengetahui fenomena belajar. Seekor kucing yang lapar ditempatkan dalam sangkar berjeruji besi yang dilengkapi dengan pengungkit, gerendel pintu, dan tali yang menghubungkan pengungkit dengan gerendel. Peralatan tersebut ditata sedemikian rupa sehingga memungkinkan kucing tersebut memperoleh makanan yang ada di depan pintu. Berdasarkan hasil eksperimennya, Thorndike menyimpulkan bahwa belajar adalah hubungan antara stimulus dan respons.

Menurut Thorndike, belajar berproses melalui trial and error (mencoba-coba dan mengalami kegagalan) dan law of effect yang berarti bahwa segala tingkah laku yang berakibatkan suatu keadaan yang memuaskan (cocok dengan tuntutan siatuasi) akan diingat dan dipelajari dengan sebaik-baiknya. ${ }^{34}$

Teori Connectionism memandang bahwa organisme (juga manusia) sebagai mekanismus yang hanya bergerak atau bertindak jika ada perangsang yang memengaruhi dirinya. Terjadinya otomatisasi dalam belajar disebabkan adanya law of effect tersebut. Karena adanya law of effect terjadilah hubungan (connection) atau asosiasi antara tingkah laku atau reaksi yang dapat mendatangnya sesuatu hasil (effect).

\section{Teori Conditioning}

Teori Conditioning ini dipelopori oleh Pavlov, seorang ahli psikologi-refleksologi dari Rusia yang menggunakan anjing dalam melakukan eksperimen. Seekor anjing dimasukkan ke dalam kamar gelap yang hanya tersedia satu lubang yang terletak di depan moncongnya sebagai tempat menyodorkan makanan atau menyorotkan cahaya pada saat diadakan percobaan. Dengan demikian, dapat diketahui keluar tidaknya air liur dari moncong anjing itu pada saat diadakan percobaan.

Pada percobaan-percobaan yang dilakukan terhadap anjing itu, Pavlov mendapatkan kesimpulan bahwa gerakan-gerakan refleks dapat dipelajari dan dapat berubah karena mendapat latihan. Terdapat dua macam refleks, yaitu refleks wajar (unconditioned reflex) sebagaimana air liur anjing yang keluar ketika melihat makanan yang lezat, dan refleks bersyarat atau refleks yang dipelajari (conditioned reflex) sebagaimana air liur anjing yang keluar karena menerima atau bereaksi dengan warna sinar tertentu atau terhadap suatu bunyi tertentu. ${ }^{35}$

Penganut teori Conditioning ini memandang bahwa segala tingkah laku manusia tidak lain adalah hasil dari conditioning, yaitu hasil dari latihan-latihan atau kebiasaan-kebiasaan mereaksi terhadap perangsang-perangsang tertentu yang dialami di dalam kehidupannya.

Setiap teori belajar menurut pandangan Ilmu Jiwa merupakan hasil eksperimen para ahli yang dapat dikembangkan dalam proses pembelajaran dengan memperhatikan kelebihan dan kekurangan teori masing-masing. Teori belajar menurut Ilmu Jiwa Daya dapat diterapkan dalam pembelajaran yang menuntut hafalan, sedangkan teori belajar menurut Ilmu Jiwa Gestalt tepat diterapkan dalam pembelajaran yang memerlukan pemahaman. Adapun teori belajar menurut Ilmu Jiwa Asosiasi tepat digunakan dalam pembelajaran yang menuntut penerapan 


\section{SIMPULAN}

Konsep belajar dan pembelajaran telah dibahas menurut tinjauan psikologi yang dihubungkan dengan teori-teori pokok tentang belajar sehingga diperoleh simpulan sebagai berikut:

1. Belajar sebagai aktivitas psiko-fisik yang menghasilkan perubahan atas pengetahuan, sikap dan keterampilan yang relatif konstan, dibedakan atas belajar abstrak, belajar keterampilan, belajar sosial, belajar pemecahan masalah, belajar rasional, belajar kebiasaan, belajar apresiasi, dan belajar pengetahuan. Hal ini telah mendapat perhatian dari para ahli pendidikan dan psikologi yang pada pokoknya memandang bahwa konsep belajar selalu menunjukkan kepada suatu proses perubahan perilaku seseorang berdasarkan praktek atau pengelaman tertentu.

2. Pembelajaran merupakan aktivitas yang berproses melalui tahapan perancangan, pelaksanaan, dan evaluasi, dimaknai sebagai interaksi peserta didik dengan pendidik dan sumber belajar dalam suatu lingkungan belajar. Oleh karena itu, keberhasilan sebuah proses pembelajaran ditentukan oleh ketiga komponen tersebut. Beberapa teori yang dapat dijadikan landasan konsep pembelajaran antara lain teori Ilmu Jiwa Daya yang beranggapan bahwa jiwa manusia mempunyai daya-daya seperti daya mengenal, daya mengingat, daya berpikir, daya fantasi yang dapat dipertajam secara fungsional untuk sesuatu hal dengan cara melatih semua daya yang tersedia. Teori belajar Ilmu Jiwa Gestalt memandang bahwa keseluruhan lebih penting dari bagian-bagian, sebab keberadaan bagian-bagian itu didahului oleh keseluruhan. Teori belajar Ilmu Jiwa Asosiasi yang dibedakan atas teori belajar Connectionism memandang bahwa belajar adalah hubungan antara stimulus dan respons, dan teori belajar Conditioning yang memandang bahwa segala tingkah laku manusia tidak lain adalah hasil dari latihan-latihan atau kebiasaan-kebiasaan mereaksi terhadap perangsang-perangsang tertentu yang dialami di dalam kehidupannya

\section{CATATAN AKHIR}

1. Republik Indonesia, Undang-undang Republik Indonesia Nomor 20 Tahun 2003 Tentang Sistem Pendidikan Nasional, cet. 1; Jakarta: BP Panca Usaha, 2003, h. 4.

2. Sardiman A.M., Interaksi dan Motivasi Belajar Mengajar, Jakarta: PT Raja Grafindo Persada, 2008, h. 13.

3. Dadang Sukirman, Microteaching, cet. 1; Jakarta: Direktorat Jenderal Pendidikan Islam Departemen Agama Republik Indonesia, 2009, h. 1.

4. Noehi Nasution, dkk., Materi Pokok Psikologi Pendidikan, Jakarta: Direktorat Jenderal Pembinaan Kelembagaan Agama Islam Dep. Agama dan Universitas Terbuka, 1991, h. 4.

5. Slameto, Belajar dan Faktor-faktor yang Mempengaruhinya, cet. 3; Jakarta: PT Rineka Cipta, 1995, h. 2.

6. Sumadi Suryabrata, Psikologi Pendidikan, cet. 17; Jakarta: Rajawali Pers, 2010), h. 271.

7. Syaiful Sagala, Konsep dan Makna Pembelajaran untuk Membantu Memecahkan Problematika Belajar dan Mengajar, cet. 8; Bandung: Alfabeta, 2010, h. 14. 
8. Slameto, op. cit., h. 14.

9. Syaiful Sagala, op. cit., h. 14.

10. Ibid., h. 25.

11. Soemiarti Patmonodewo, Pendidikan Anak Prasekolah, Cet. 2; Jakarta: Pusat Perbukuan Dep. Pendidikan \& Kebudayaan Bekerjasama dengan PT Rineka Cipta, 2003, h. 11.

12. Syaiful Sagala, op. cit., h. 29.

13. Soemiarti Patmonodewo, op. cit., h. 14.

14. Syaiful Sagala, op. cit., h. 33

15. Ibid., h. 26.

16. Ibid., h. 36 .

17. Syaiful Bahri Djamarah, Psikologi Belajar, Jakarta: Rineka Cipta, 2008, h. 27.

18. Muhibbin Syah, Psikologi Pendidikan dengan Pendekatan Baru, cet. 15; Bandung: PT Remaja Rosdakarya, 2010, h. 120.

19. Kementerian Agama Republik Indonesia, Materi Peningkatan Kualitas Guru Pendidikan Agama Islam Tingkat SD/SMP/SMA/SMK, Jakarta: Direktorat Pendidikan Agama Islam, 2012, h. 220.

20. Tohirin, Psikologi Pembelajaran Pendidikan Agama Islam (Berbasis Integrasi dan Kompetensi): Sumbangan Psikologi Pembelajaran Terhadap Peningkatan Kompetensi Guru Pendidikan Agama Islam, Jakarta: PT Raja Grafindo Persada, 2008, h. 101.

21. Muhibbinsyah, op. cit., h. 120.

22. Ibid., h. 121.

23. Tohirin, op. cit., h. 102

24. Muhibbinsyah, op. cit., h. 103.

25. Ibid., h. 122.

26. Ibid.

27. Republik Indonesia, Undang-Undang Republik Indonesia Nomor 20 Tahun 2003 tentang Sistem Pendidikan Nasional, Cet. 1; Jakarta: BP Panca Usaha, 2003, h. 6.

28. Wina Sanjaya, Kurikulum dan Pembelajaran: Teori dan Praktik Pengembangan Kurikulum Tingkat Satuan Pendidikan (KTSP), cet. 1; Jakarta: Kencana, 2008, h. 195.

29. Syaiful Sagala, op. cit., h. 63.

30. Muhibbinsyah, op. cit., h. 102.

31. Syaiful Bahri Djamarah, op. cit., h. 17.

32. Ibid., h. 19.

33. M. Ngalim Purwanto, Psikologi Pendidikan, Cet. 23; Bandung: PT Remaja Rosdakarya, 2007, h. 100.

34. Ibid., h. 99.

35. Ibid. h. 90 .

\section{DAFTAR PUSTAKA}

Djamarah, Syaiful Bahri. Psikologi Belajar. Jakarta: Rineka Cipta, 2008.

Kementerian Agama Republik Indonesia. Materi Peningkatan Kualitas Guru Pendidikan Agama Islam Tingkat SD/SMP/SMA/SMK. Jakarta: Direktorat Pendidikan Agama Islam, 2012. 
Muhibbin Syah. Psikologi Pendidikan dengan Pendekatan Baru. Cet. 15; Bandung: PT Remaja Rosdakarya, 2010.

Nasution, Noehi, dkk. Materi Pokok Psikologi Pendidikan. Jakarta: Direktorat Jenderal Pembinaan Kelembagaan Agama Islam Departemen Agama dan Universitas Terbuka, 1991.

Patmonodewo, Soemiarti. Pendidikan Anak Prasekolah. Cet. 2; Jakarta: Pusat Perbukuan Departemen Pendidikan \& Kebudayaan Bekerjasama dengan PT Rineka Cipta, 2003.

Purwanto, M. Ngalim. Psikologi Pendidikan. Cet. 23; Bandung: PT Remaja Rosdakarya, 2007.

Slameto. Belajar dan Faktor-faktor yang Mempengaruhinya. Cet. 3; Jakarta: PT Rineka Cipta, 1995.

Republik Indonesia. Undang-Undang Republik Indonesia Nomor 20 Tahun 2003 Tentang Sistem Pendidikan Nasional. Cet. 1; Jakarta: BP Panca Usaha, 2003.

Sagala, Syaiful. Konsep dan Makna Pembelajaran untuk Membantu Memecahkan Problematika Belajar dan Mengajar. Cet. 8; Bandung: Alfabeta, 2010.

Sanjaya, Wina. Kurikulum dan Pembelajaran: Teori dan Praktik Pengembangan Kurikulum Tingkat Satuan Pendidikan (KTSP). Cet. 1; Jakarta: Kencana, 2008.

Sardiman, A.M. Interaksi dan Motivasi Belajar Mengajar. Jakarta: PT Raja Grafindo Persada, 2008.

Sukirman, Dadang. Microteaching. Cet. 1; Jakarta: Direktorat Jenderal Pendidikan Islam Departemen Agama Republik Indonesia, 2009.

Suryabrata, Sumadi. Psikologi Pendidikan. Cet. 17; Jakarta: Rajawali Pers, 2010.

Tohirin. Psikologi Pembelajaran Pendidikan Agama Islam (Berbasis Integrasi dan Kompetensi): Sumbangan Psikologi Pembelajaran Terhadap Peningkatan Kompetensi Guru Pendidikan Agama Islam. Jakarta: PT Raja Grafindo Persada, 2008. 